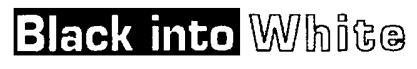





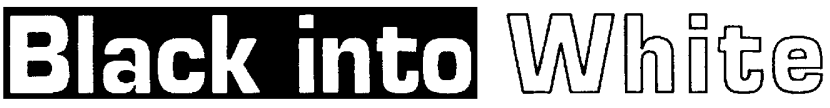

\section{Race and Nationality in}

\section{Brazilian Thought}

With a Preface to the 1993 Edition and Bibliography

\section{Thomas E. Skidmore}

Duke University Press Durham and London 1993 
Third printing, 1998

(C) 1993 Duke University Press

All rights reserved

Originally published by Oxford University Press in 1974

Printed in the United States of America on acid-free paper $\infty$

Library of Congress Cataloging-in-Publication Data appear on the last printed page of this book. 
For my parents

who took a lively interest 
